\title{
Spatiotemporal variation in global floods with different affected areas and the contribution of influencing factors to flood-induced mortality (1985-2019)
}

\author{
Tian Liu' ${ }^{1,3} \cdot$ Peijun Shi ${ }^{1,2,3} \cdot$ Jian Fang ${ }^{4}$
}

Received: 16 August 2021 / Accepted: 25 November 2021 / Published online: 1 January 2022

(c) The Author(s) 2021

\begin{abstract}
Floods are great threats to human life and property. Extensive research has investigated the spatiotemporal variation in flood occurrence, while few have studied the heterogeneity in global flood events of different sizes, which may require different coping strategies and risk reduction policies. In this study, we analysed the spatiotemporal patterns of global flood events with different affected areas (classified in three levels) during 1985-2019 and examined the contribution of different influencing factors to flood-induced mortality using Geodetector. The results show that (1) the increase in global flood frequency was mainly caused by Level II and Level III floods, and the average area affected by flood events has been increasing yearly since 1985. (2) In America and Africa, the frequency of Level III floods has increased monotonically. At the same time, the frequency of Level I floods in Europe and Level II floods in Asia has increased significantly. (3) For Europe and Asia, most of the deaths occurred with Level II floods; while for America and Africa, Level III floods caused the most mortality. (4) The top three factors contributing to the spatial heterogeneity in flood-induced mortality were the affected population, GDP per capita and flood duration. The contribution of each factor varied among the different types of floods. Topographic factors (percentage of mountainous area) magnified flood-induced mortality during extreme events with heavy rainfall, especially for Level III floods. The heterogeneity in flood frequency and flood-induced mortality indicates that flood protection measures should be more targeted. In addition, the increase in large-scale floods (Level III) highlights the need for transregional cooperation in flood risk management.
\end{abstract}

Keywords Spatiotemporal variation · Flood-induced mortality · Global analysis · Mountainous area $\cdot$ Influencing factor

Peijun Shi

spj@bnu.edu.cn

1 Institute of Disaster Risk Science, Faulty of Geographical Science, Beijing Normal University, Haidian District, No. 12, Xueyuan south St., Beijing 100875, China

2 Academy of Plateau Science and Sustainability, Qinghai Normal University, Xining 810008, China

3 Faculty of Geographical Science, Beijing Normal University, Beijing 100875, China

4 College of Urban and Environmental Sciences, Central China Normal University, Wuhan 430079, China 


\section{Introduction}

Floods are among the most severe climate-related disasters, which pose a great threat to human life and property (Hirabayashi et al. 2013; Hu et al. 2018). Impacts related to global warming, such as rising sea levels, stronger precipitation and greater river runoff, are likely to cause an increase in global flood frequency and extent (Jonkman 2005). The area and number of people affected by floods in Europe have increased every year since 1870 (Paprotny et al. 2018a). The impact of floods on humans is also expected to increase due to growth of the population and economy (Tanoue et al. 2016). At present, the extent to which changes in hazards, exposure, and the environment affect floods and loss of life at the global scale is not yet well understood. Studying the influencing factors of flood disasters could help reduce their societal impacts.

There is a positive correlation between the magnitude and extent of most floods (Kemter et al. 2020). The societal impacts of floods vary with the size of the affected area; the management of and response to floods also adapt to flood scales. Small floods tend to be managed by local communities and thus rely on local flood management programmes. For large floods, there is a need for cross-provincial cooperation (as in the case of the 1998 mega-flood in China) (Du et al. 2019), or even transnational cooperation and mutual assistance (e.g. floods caused by monsoon rains in South Asia). Emergency response and disaster recovery are stressful because they need to be implemented in multiple locations simultaneously with large affected areas (Jongman et al. 2014). Therefore, this study divided flood events into three categories by taking $2 \times 10^{4} \mathrm{~km}^{2}$ and $10 \times 10^{4} \mathrm{~km}^{2}$ as classification standards and attempted to analyse the spatiotemporal patterns of global floods with different affected areas to provide information that can help governments and institutions craft macro-decisions related to flood risk management at different scales.

Several previous studies have explored the spatial-temporal variation in flood-induced mortality and its influencing factors at the global, continental and national scale (Jonkman 2005; Jonkman and Kelman 2005; Fitzgerald et al. 2010; Stevens et al. 2016; Halgamuge and Nirmalathas 2017; Hu et al. 2018). Globally, flood-induced mortality first increased and then decreased from 1975 to 2002 with the growth in per capita GDP (Kellenberg and Mobarak 2008). The higher the density of population and wealth, the higher the sensitivity of a region to floods (Hu et al. 2018; Shen and Hwang 2019). Regionally, while some studies have calculated the relationship among flow velocity, water depth and floodinduced mortality rates based on historical flood events (Jonkman et al. 2009; Di Mauro et al. 2012), it is usually difficult to obtain accurate data on flood inundation extent and water depth in large-scale and multiple case studies. The growth of population, economy and urbanization are the most important factors contributing to the increase in flood exposure for coastal cities (Hanson et al. 2011); land use has also been found to affect flood damage (Jongman et al. 2012; Neumann et al. 2015). However, there have been no studies investigating the difference in the frequency and mortality of global floods with different sizes as well as their influencing factors.

The spatial heterogeneity of flood hazards and the losses they caused are closely related to environmental factors, including terrain, vegetation cover, and soil (Shi 2019). By analysing the cumulative distribution of flood events and their related mortality along elevation, slope, and distance from the coast, it was found that floods occur most frequently in regions with low and flat terrain and dense river systems (Hu et al. 2018). Zhao et al. (2018) used the random forest method to calculate the susceptibility of floods in mountainous areas of China, in which geographical elements, including latitude, longitude, 
elevation, and slope, were considered. However, if the area affected by floods is large, then it is not appropriate to use the elevation and slope at the centre of the affected area or their average value to characterize the topography. In general, there have been few studies regarding the impacts of geographical environment on flood-induced losses, especially on the quantitative analysis of impacts on the spatial heterogeneity of flood-induced mortality at the global scale.

Additionally, most previous studies were based on the annual aggregation of all flood events and damage within a country. These studies focused on statistics, which could result in the loss of information on the intensity and location of individual flood events. Using specific information of individual flood events, Chen et al. (2020a) found that flood events with low intensities but high frequencies may cause similar amounts of or even more deaths than those with high intensities but low frequencies. Therefore, analysing the distribution of individual flood events in addition to their annual aggregations and national statistics would contribute to a deeper understanding of flood hazards and risks.

Based on the above analyses, this study aims to (1) examine the trends and distributions of flood occurrence and mortality with different affected areas at different scales; (2) investigate the contribution rate of each influencing factor, especially the topographic factor, to the spatial heterogeneity of flood-induced mortality; and (3) compare the contribution rates of influencing factors to mortality from floods with different affected areas. The results would enhance the understanding of the relationship between the spatiotemporal patterns of flood-induced mortality and their influencing factors and provide a theoretical basis for decision-making related to flood risk reduction.

\section{Data and methods}

\subsection{Data}

Global flood disaster data were obtained from the Dartmouth Flood Observatory (DFO) database, which contains information on global flood events from 1985 to the present from news, governmental, instrumental, and remote sensing sources. The information in the database includes the latitude, longitude, start time and end time of each flood event; floodinduced mortality caused and the affected population, as well as the extent of the affected area (GIS files). The extent of the affected area for every individual flood event was critical for this study, as it enables event-based analysis of flood impacts and influencing factors. Many researchers have used this database to analyse flood disasters and evaluated the reliability of this database (Halgamuge and Nirmalathas 2017; Hu et al. 2018; Koç and Thieken 2018; Najibi and Devineni 2018; Chen et al. 2020b). The comparison of DFO database and other disaster database (e.g. Emergency Events Database EM-DAT and European historical flood database HANZE) revealed that the information of flood events recorded in DFO database is reliable and complete, especially for a global scale analysis. More details about the uncertainty and reliability of the DFO database are provided in the Appendix. In addition, global datasets of rainfall, mountainous areas, and socioeconomic indicators were also used (Table 1).

To characterize the topographical factor, this study calculated the mountainous area percentage within a flood-affected region. The mountainous area is defined by the combination of elevation, slope and relative elevation using the criteria in Table 2. 


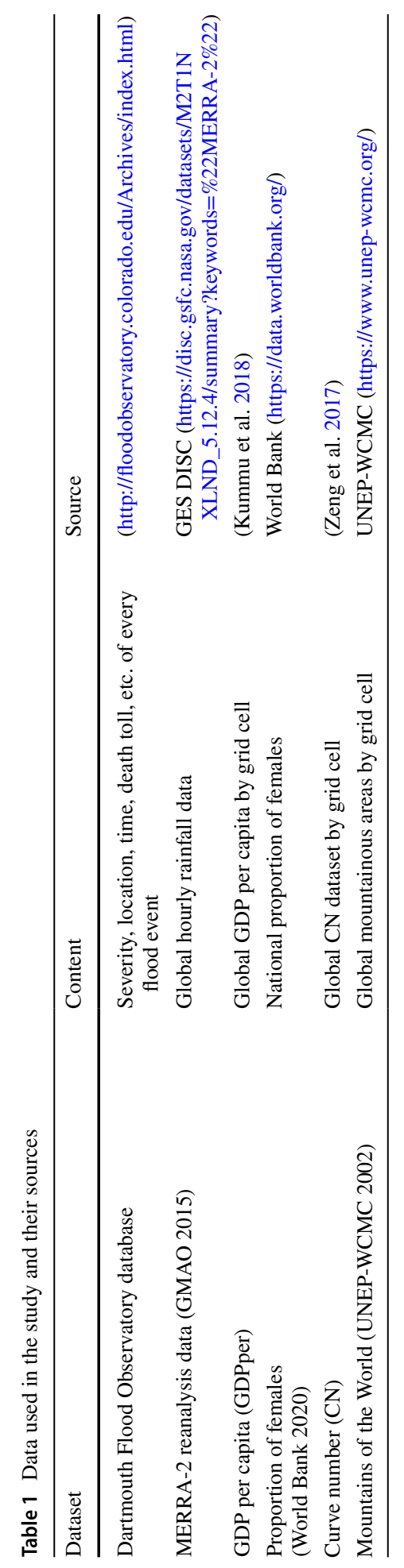


Table 2 Definition of mountainous areas by the UNEP (2002)

\begin{tabular}{ll}
\hline \multicolumn{1}{l}{ Mountainous area criteria } \\
\hline 1 & Elevation $>2500 \mathrm{~m}$ \\
2 & $1500 \mathrm{~m}<$ elevation $\leq 2500 \mathrm{~m}$ and slope $>2^{\circ}$ \\
3 & $1000 \mathrm{~m}<$ elevation $\leq 1500 \mathrm{~m}$ and slope $>5^{\circ}$ \\
4 & $300 \mathrm{~m}<$ elevation $\leq 1000 \mathrm{~m}$ and relative elevation $>300 \mathrm{~m}$ within $7 \mathrm{~km}$ radius \\
5 & Inner isolated areas $\left(\leq 25 \mathrm{~km}^{2}\right.$ in size $)$ that do not meet the criteria but are \\
& surrounded by mountains \\
\hline
\end{tabular}

\subsection{Methods}

(1) Flood classification and influencing factors.

In this study, we divided all flood events into three categories: Level I (affected area $\left.<2 \times 10^{4} \mathrm{~km}^{2}\right)$, Level II $\left(2 \times 10^{4} \leq\right.$ affected area $\left.<10 \times 10^{4} \mathrm{~km}^{2}\right)$, and Level III (affected area $\geq 10 \times 10^{4} \mathrm{~km}^{2}$ ) according to the standards noted in previous studies (Berghuijs et al. 2019; Kemter et al. 2020). It is worth noting that all the events in this database are generally large floods, and small flood events with limited impacts are not included. We believe that even though they are all large floods, the discrimination of flood events by different affected areas is necessary, as they may be transregional, transprovincial or transnational, requiring different coping strategies.

Flood disasters are complex systems which include the hazards, disaster-formative environments, and exposure. The natural environment and human societies interact with each other to produce adverse consequences (Shi 1996). Studies have generally identified heavy rainfall as a key flooding component (Villarini et al. 2011). We chose extreme rainfall (maximum hourly precipitation during every individual flood event) and flood duration to represent hazard factors influencing mortality. For topographic factors, we used the percentage of mountainous area (a composite indicator of elevation and slope) in the area affected by floods. In addition, land use/land cover and soil moisture also have a significant impact on flood occurrence and magnitude as they can affect the process of rainfall percolation and runoff generation. Therefore, the curve number $(\mathrm{CN}$, mean value in the affected area) was chosen to represent the hydrological conditions. Previous studies have shown that the scale of exposure, coping capacity and gender have an important impact on flood-induced mortality (Jonkman and Kelman 2005; Shi et al. 2016; Shi 2019; Naz and Saqib 2021). Therefore, the population affected by floods, GDP per capita (mean value in affected area) and the female percentage within the total population were also selected as influencing factors.

(2) Mann-Kendall trend test.

The Mann-Kendall (MK) trend test (Mann 1945) was used to detect flood frequency trends in this study. It is a widely used statistical method to detect trends in time series and has been adopted in many hydrometeorological studies (Delgado et al. 2010; Najibi and Devineni 2018; Ali et al. 2019). The magnitude of a trend is measured by Sen's slope (Sen 1968; Kendall 1975); a positive MK statistic Z and Sen's slope indicate an increasing trend, and vice versa. $|Z|>1.96$ rejects the null hypothesis "no trend in the time series" at the 5\% significance level, and $|Z|>1.645$ rejects the null hypothesis at the $10 \%$ significance level.

(3) Geographical detector (Geodetector). 
Geographical detector (or Geodetector) is a statistical method for spatial heterogeneity and driving factor detection based on spatial variance analysis. It can be applied to both continuous numerical variables and discrete factors and does not need to consider the collinearity among independent variables (Wang et al. 2010; Cao et al. 2013; Wang and Xu 2017). Its initial application was in determining health risks, where it is used to identify which and to what extent environmental factors contribute to health risks (Wang et al. 2010; Wang and Hu 2012; Luo et al. 2019). For natural disasters, Hu et al. (2011) used Geodetector to analyse the relationship between earthquake mortality and earthquake intensity, collapsed buildings and slopes.

The Geodetector model was used to quantitatively analyse the contribution of influencing factors (as mentioned in Sect. 2.2(1)) to the spatial heterogeneity of flood-induced mortality (refers to the number of deaths) in this study. Flood-induced mortality was used as a dependent variable, while the influencing factors were considered as independent variables. The contribution rate was measured by $q$ based on the assumption that if an independent variable has an important impact on the dependent variable, then their spatial distribution should be similar. The calculation formula of $q$ is as follows:

$$
q=1-\frac{\sum_{h=1}^{L} N_{h} \sigma_{h}^{2}}{N \sigma^{2}}
$$

where $L$ is the number of layers (categories or partitions) of the influencing factor, $N_{h}$ is the number of flood events resulting in death within the $h$-th layer, and $\sigma_{h}^{2}$ and $\sigma^{2}$ are the flood-induced mortality variance of the $h$-th layers and all the samples, respectively. The value of $q$ varies in the range of 0 to 1 ; the higher the value of $q$ is, the greater the impact of the influencing factor on mortality. That is, the value of $q$ means that the influencing factor explains $100 * q \%$ of the flood-induced mortality. By comparing the $q$ value of the influencing factors, we can explore which factors are more significant in controlling the spatial pattern of flood-induced mortality (Wang et al. 2010; Hu et al. 2011; Wang and Xu 2017). Every variable was discretized according to the principle of maximizing $q$ value or professional knowledge (Cao et al. 2013; Song et al. 2020).

\section{Results}

\subsection{Temporal variation in flood occurrences with different affected areas}

There were 1279 Level III floods, 1718 Level II floods, and 1852 Level I floods during 1985-2019. The median and 90th percentile of deaths in descending order were Level III > Level II > Level I. Level II floods have the highest average amount of deaths. This may have been due to severe casualties caused by some individual flood events, such as the floods in Bangladesh in 1991 and Myanmar in 2008, and the impact of individual disastrous events was also reflected in the large standard deviation of Level II flood mortality (Table 3). At a global scale, annual flood occurrence showed an increasing trend during the study period (with a $\mathrm{Z}$ value of 2.08 in the MK test). The monotonous increasing trend of global flood frequency was mainly caused by the increase in Level II and Level III flood frequencies, while Level I floods show an decreasing trend but not significant (Fig. 1 and Table 4). We also found that the average area affected by individual flood event increased yearly at a global scale (Table 4). 
Table 3 Statistics for the occurrence and mortality of floods with different affected areas

Fig. 1 Time series of global flood occurrence (1985-2019) by affected area

\begin{tabular}{llll}
\hline & Level I & Level II & Level III \\
\hline Total flood frequency & 1852 & 1718 & 1279 \\
Mean mortality (person) & 27 & 277 & 116 \\
Median mortality (person) & 3 & 5 & 10 \\
P90 of mortality (person) & 34 & 70 & 169 \\
Standard deviations & 266.08 & 5640.49 & 755.49 \\
\hline
\end{tabular}

P90: the 90th percentile of deaths per flood event

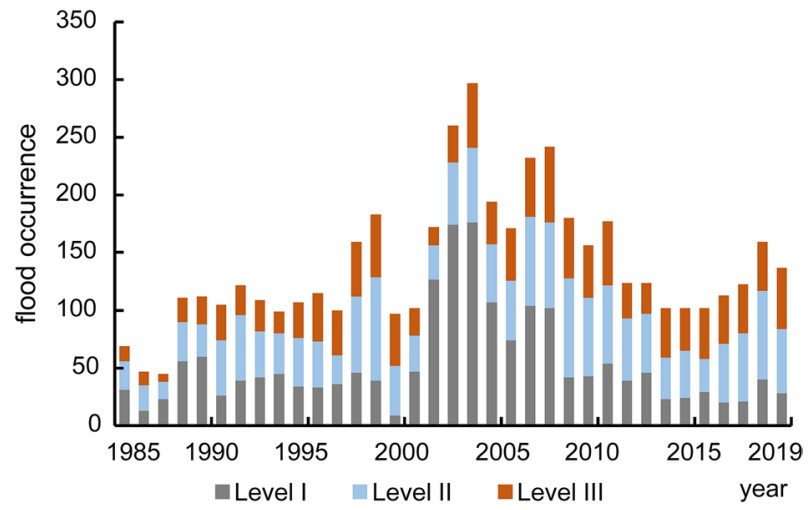

Table 4 Trends in global flood occurrence and affected area per event

\begin{tabular}{llrrrr}
\hline & & Z & P & Sen's slope & Trend \\
\hline Frequency & Global & 2.08 & 0.04 & 1.50 & $+^{* *}$ \\
& Level I floods & -0.17 & 0.87 & -0.08 & - \\
& Level II floods & 2.99 & 0.00 & 0.89 & $+^{* *}$ \\
& Level III floods & 3.54 & 0.00 & 0.88 & $+{ }^{* *}$ \\
Affected area per event & mean & 2.13 & 0.03 & 1069.24 & $+{ }^{* *}$ \\
\hline
\end{tabular}

$+* *$ : Increasing trend significant at the 5\% significance level, -: Decreasing trend but not significant

At the continental scale, Level II and Level III floods in Africa, South America, and Oceania had a tendency to increase at the 5\% significance level (Table 5), and Level III floods exhibited the largest trends. Level II floods in Asia had a monotonous increasing trend at the $10 \%$ significance level. Europe was dominated by Level I and Level II floods, and only the Level I floods showed an increasing trend at the 10\% significance level; North America was dominated by Level I and Level II floods, and only Level III floods increased yearly at the 5\% significance level. 
Table 5 Trends in flood frequency by affected area and on different continents

\begin{tabular}{|c|c|c|c|c|c|c|c|c|c|}
\hline \multirow[t]{2}{*}{ Continent } & \multicolumn{3}{|c|}{ Level I floods } & \multicolumn{3}{|c|}{ Level II floods } & \multicolumn{3}{|c|}{ Level III floods } \\
\hline & $\begin{array}{l}\text { Occur- } \\
\text { rence/ } \\
\text { year }\end{array}$ & $\mathrm{Z}$ & Sen's slope & $\begin{array}{l}\text { Occur- } \\
\text { rence / } \\
\text { year }\end{array}$ & $\mathrm{Z}$ & Sen's slope & $\begin{array}{l}\text { Occur- } \\
\text { rence/ } \\
\text { year }\end{array}$ & $\mathrm{Z}$ & Sen's slope \\
\hline Africa & 7 & 1.41 & 0.10 & 7 & 3.45 & 0.25 & 7 & 4.12 & 0.28 \\
\hline Asia & 23 & -0.53 & -0.15 & 23 & 1.89 & 0.29 & 14 & 1.21 & 0.11 \\
\hline Europe & 7 & 1.91 & 0.13 & 6 & 1.53 & 0.10 & 3 & 0.93 & 0.00 \\
\hline $\begin{array}{l}\text { North } \\
\text { America }\end{array}$ & 10 & -1.18 & -0.10 & 8 & 1.26 & 0.08 & 5 & 2.24 & 0.12 \\
\hline South America & 3 & -1.57 & -0.04 & 3 & 2.25 & 0.04 & 6 & 4.09 & 0.21 \\
\hline Oceania & 3 & 0.49 & 0.00 & 2 & 2.67 & 0.06 & 2 & 3.95 & 0.10 \\
\hline
\end{tabular}

Occurrence/year: average annual occurrence was rounded down to integral numbers; $|Z|>1.96$ : trend significant at the $5 \%$ significance level, $|\mathrm{Z}|>1.645$ : trend significant at the $10 \%$ significance level

\subsection{Spatial distribution of flood frequency and mortality with different affected areas}

Using the affected area for each flood event given in the DFO database, we obtained the spatial distribution of global flood occurrence during the study period (Fig. 2). The regions with high flood frequency were mainly distributed in the low latitude areas of the Northern Hemisphere and coastal areas, such as the Yangtze River Basin and coastal areas in eastern Asia, the Ganges-Brahmaputra River Basin in South Asia, and the

(a)

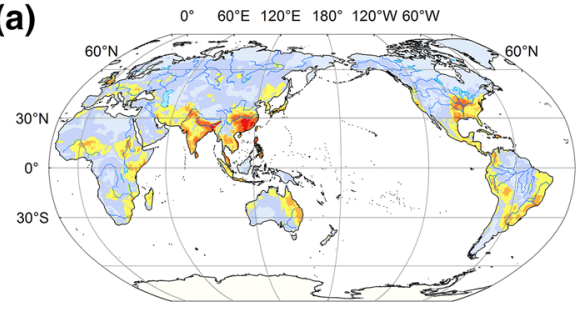

Flood occurrence $\square 0 \square$ 0-4 $\square$ 4-10 $\square$ 10-17 $\square$ 17-30 $\square$ >30

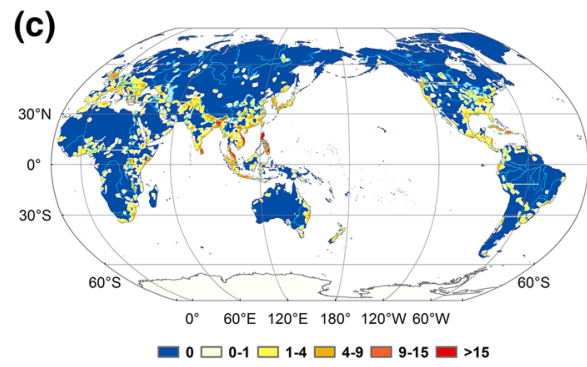

(b)

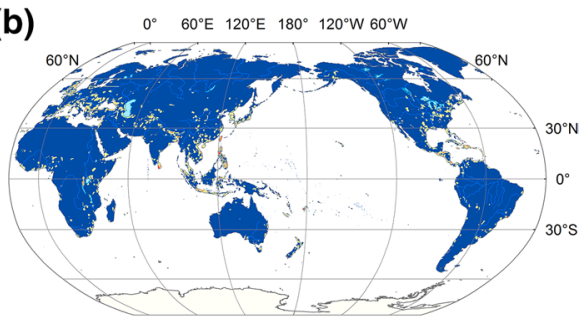

$=0 \square$ 0-3 $\square$ 3-8 $\square>8$

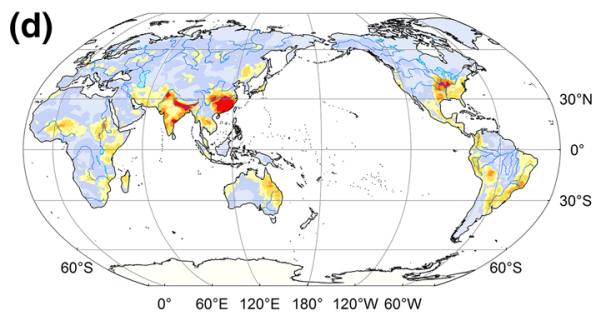

$\square 0 \square 0-3 \square 3-7 \square 7-12 \square 12-18 \square>18$

Fig. 2 Global distribution of flood occurrence for (a) all floods, b Level I floods, c Level II floods, d Level III floods 
Mississippi River Basin in North America. In Africa, flood-prone areas were found near the Nile River, Niger River, and the eastern coast of Africa; floods in South America mainly occurred along the eastern seaboard and the Magdalena River in the northwest. Level I floods mostly occurred in Southeast Asia, the Ganges River Basin, the northern Mediterranean Sea, around the Black Sea, and along the coast of Latin America and island countries (Fig. 2b). Level II floods were more distributed in the northern Bay of Bengal, Southeast Asia, the northern Mediterranean of the Danube River Basin in Europe, eastern North America and Latin America (Fig. 2c). Level III floods mainly occurred in South Asia and the Yangtze River Basin and along the eastern coast of China and the Mississippi River Basin (Fig. 2d).

For flood-induced mortality, Level III floods in Africa and South America caused the highest proportion of cumulative deaths ( $48 \%$ and $83 \%$ of all levels on each continent) (Fig. 3b) and had the largest proportion of affected populations (77\% and 62\%, respectively) (Fig. 3c), while South America had the highest proportion of Level III floods (49\%) (Fig. 3a). Asia had the largest proportion of cumulative mortality (79\%) resulting from Level II floods but also had the largest proportion of cumulative affected population (71\%) in Level III floods. Europe had the lowest number of Level III floods (18\%) and the lowest proportion of cumulative related mortality (19\%) but had the highest proportion of people affected (53\%); of the floods in Europe, $44 \%$ were Level I floods. Level III floods in North America caused the largest proportion of cumulative deaths (54\%), but Level II floods affected the largest proportion of cumulative population (78\%) among three level floods. For Oceania, Level I floods occurred at the highest frequency (39\%) and resulted in the greatest cumulative mortality (56\%) and most affected populations $(53 \%)$.
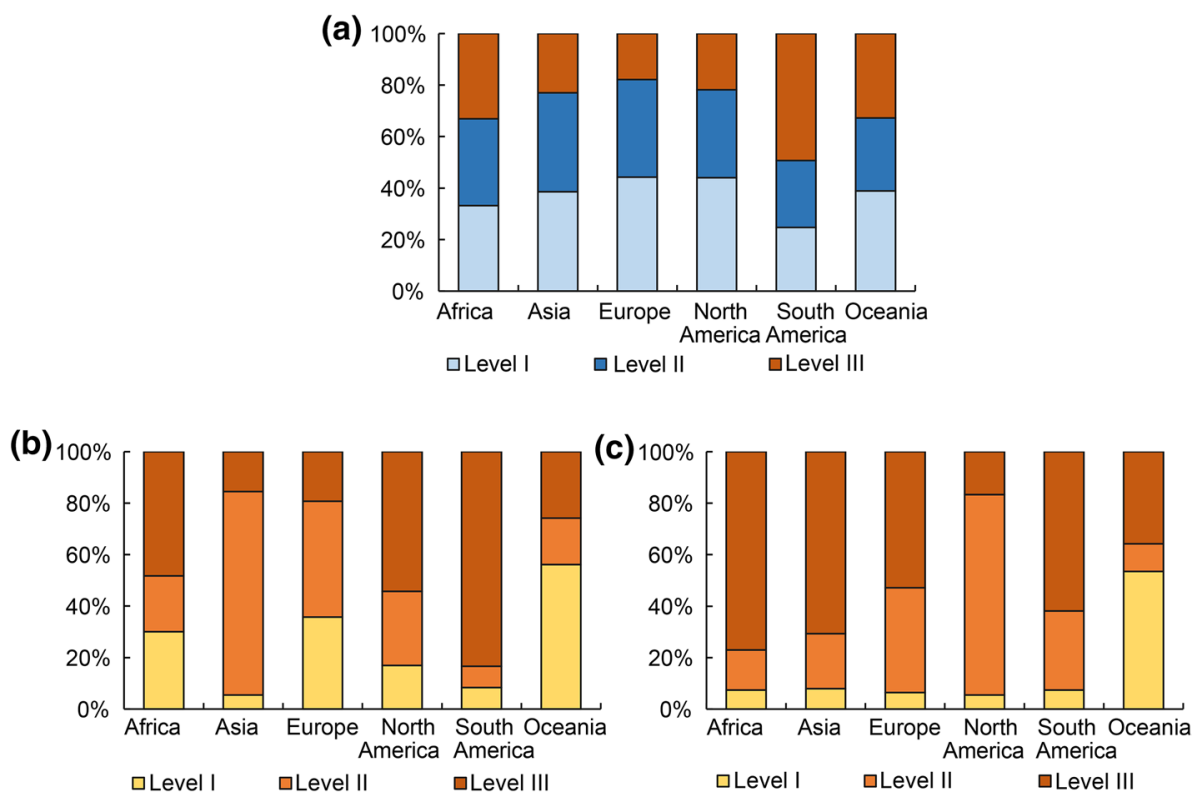

Fig. 3 Proportion of flood occurrence (a), cumulative deaths (b) and affected population (c) for floods of different sizes on different continents 


\subsection{Frequency and mortality of floods with different affected areas in the top $\mathbf{3 0}$ countries}

We selected the top 30 countries with the highest flood frequencies, flood-induced mortalities and affected populations, respectively, and analysed the proportion of floods by different categories of affected areas in these countries. In countries with less than 70 floods over the study period, the proportion of Level I floods was approximately $40-60 \%$, and the proportion of Level III floods was approximately 10-30\%. Countries with more than 70 floods had approximately $20-50 \%$ Level I floods, and the proportion of Level II floods was approximately 30-50\% (Fig. 4a).

The top ten countries most frequently affected by floods were the USA, China, India, Indonesia, the Philippines, Australia, Vietnam, Russia, Brazil, and Bangladesh. The USA had the highest flood frequency (467 flood events), with no significant difference in the proportion of Level I (37\%) and Level II floods (36\%). However, the USA ranked 14 th in the world in terms of flood-induced mortality; $49 \%$ of the deaths were caused by Level III floods (Fig. 4b), which accounted for $27 \%$ of all flood events in the USA. During 1985-2019, there were 396 floods in China; the proportions of Level I, Level II and Level III floods were $31 \%, 28 \%$ and $41 \%$, respectively; the deaths caused by Level III floods accounted for $64 \%$ of the flood-induced mortalities, and the affected population

(a)

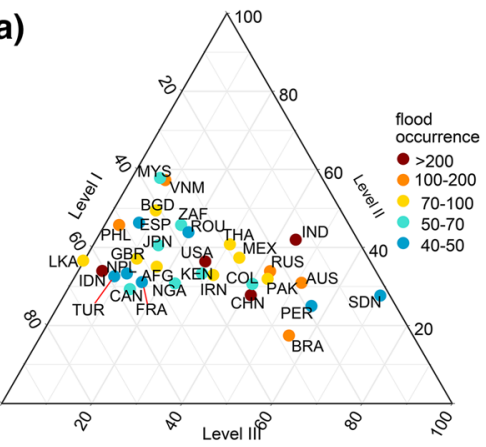

(c)

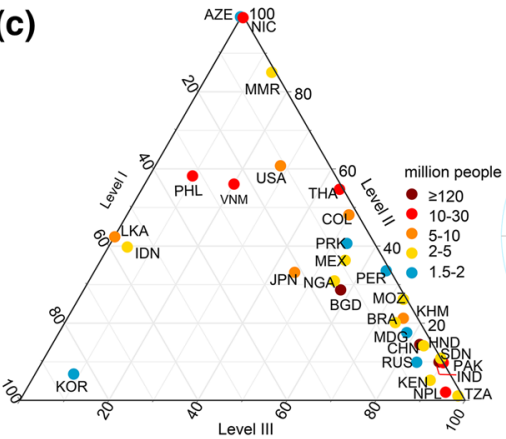

(b)

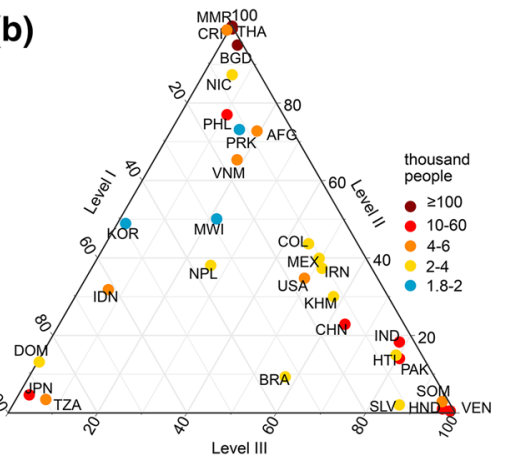

(d)

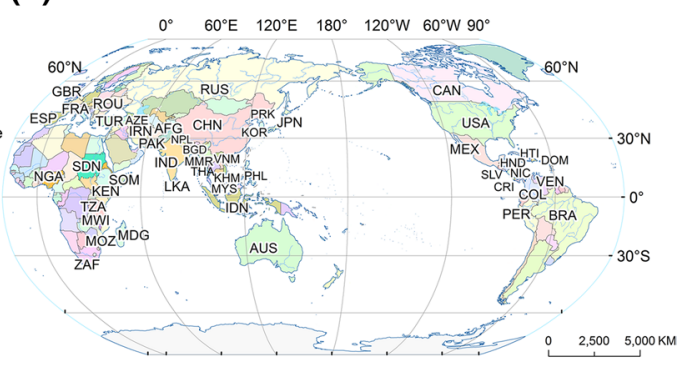

Fig. 4 Top 30 countries with the highest flood frequencies (a), flood-induced mortalities (b), and affected populations (c) and the proportion of different categories of floods in these countries and the distribution of these countries around the world $(\mathbf{d})$ 
accounted for $83 \%$. In India, of the three categories of floods, Level III floods occurred the most frequently and resulted in the most deaths and affected populations.

In Fig. 4b, approximately three-quarters of the dots are distributed close to the hypotenuse on the right side of the triangle, indicating that flood-induced mortalities in these countries were mainly caused by Level II or Level III floods. Thailand, Bangladesh, and Myanmar, at the top corner of the triangle, were the top three countries with the highest flood-induced mortality in the world, with most of the deaths caused by Level II floods. In Venezuela, India, Pakistan, and Somalia, at the bottom right of the triangle, the majority of deaths have been caused by Level III floods; Level I floods caused over half of the deaths in only four countries (Japan (93\%), Tanzania (90\%), Dominican (86\%) and Indonesia (62\%)) of the 30 countries. For South Korea, the proportions of mortality caused by Level I and Level II floods were $49.3 \%$ and $48.9 \%$, respectively. In Fig. 4c, most of the countries are located in the lower half of the right hypotenuse of the triangle, indicating that most floodaffected populations were caused by Level III floods. In addition, at the top of the triangle, the cumulative population affected by Level II floods in Nicaragua (20 flood events) and Myanmar (25 flood events) accounted for $99 \%$ and $85 \%$ of the total affected populations, respectively; Level I floods accounted for $85 \%, 57 \%$ and $56 \%$ of the affected populations in South Korea (33 flood events), Sri Lanka (58 flood events) and Indonesia (206 flood events), respectively. These differences in flood-affected populations support the need for different countries to implement appropriate flood coping strategies and prevention measures. In particular, Level III floods warrants special concern. These floods generally caused a greater proportion of deaths and affected people, although they are not the most frequent type of floods in some countries.

\subsection{Event-based analysis of influencing factors and contributions to flood-induced mortality}

For this study, we selected flood events during the period 2001-2019 according to overall data availability and used Geodetector to calculate the contribution rate of each factor to the spatial heterogeneity of the mortality caused by individual flood events.

The main influencing factors were affected population and per capita GDP. The contribution rates of the influencing factors significant at the $5 \%$ level, in descending order, were affected population $(26.0 \%)>$ GDPper $(10.7 \%)>$ flood duration $(8.9 \%)>$ female $(\%$ of total population) $(5.5 \%)>$ maximum hourly precipitation $(4.9 \%)>$ affected area $(4.4 \%)>$ curve number $(2.1 \%)>$ mountainous area ratio $(1.5 \%)$ (Fig. 5).

Fig. 5 Contribution of influencing factors to the heterogeneity of flood-induced mortality

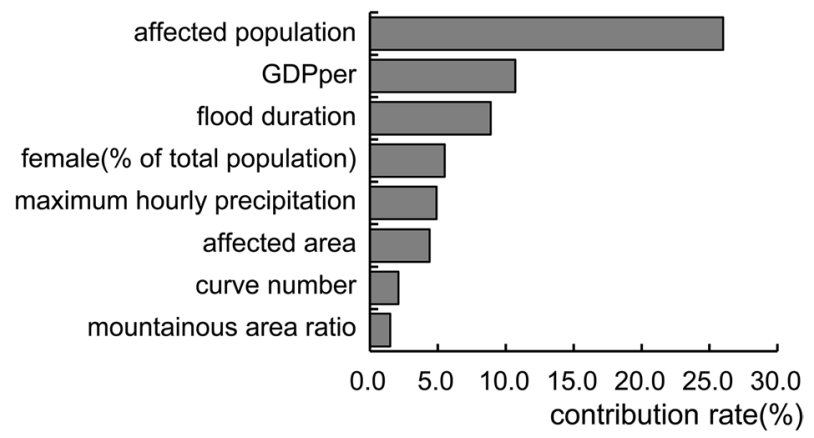


The eight significant influencing factors were further divided into several groups to examine the corresponding distribution of flood-induced mortality (Fig. 6). The number of deaths per event increased with flood duration, maximum hourly precipitation, affected area and population. As shown in Fig. 6, flood-induced mortality first increased with economic development (GDP per capita) and then decreased as more investments can be put on flood prevention measures. The mortality per flood event decreased with an increase in the proportion of females. When the curve number value was less than 79 , flood-induced mortality increased as the curve number increased. The proportion of mountainous area is an integrated indicator that represents topographic factors. In areas with mountainous area ratio lower than $20 \%$, the death per flood increased with the increase in mountainous area ratio. When the percentage of mountainous area was greater than $20 \%$, the same rule was applied. The affected area with a mountainous area ratio between 3 and $20 \%$ had the highest mean mortality.
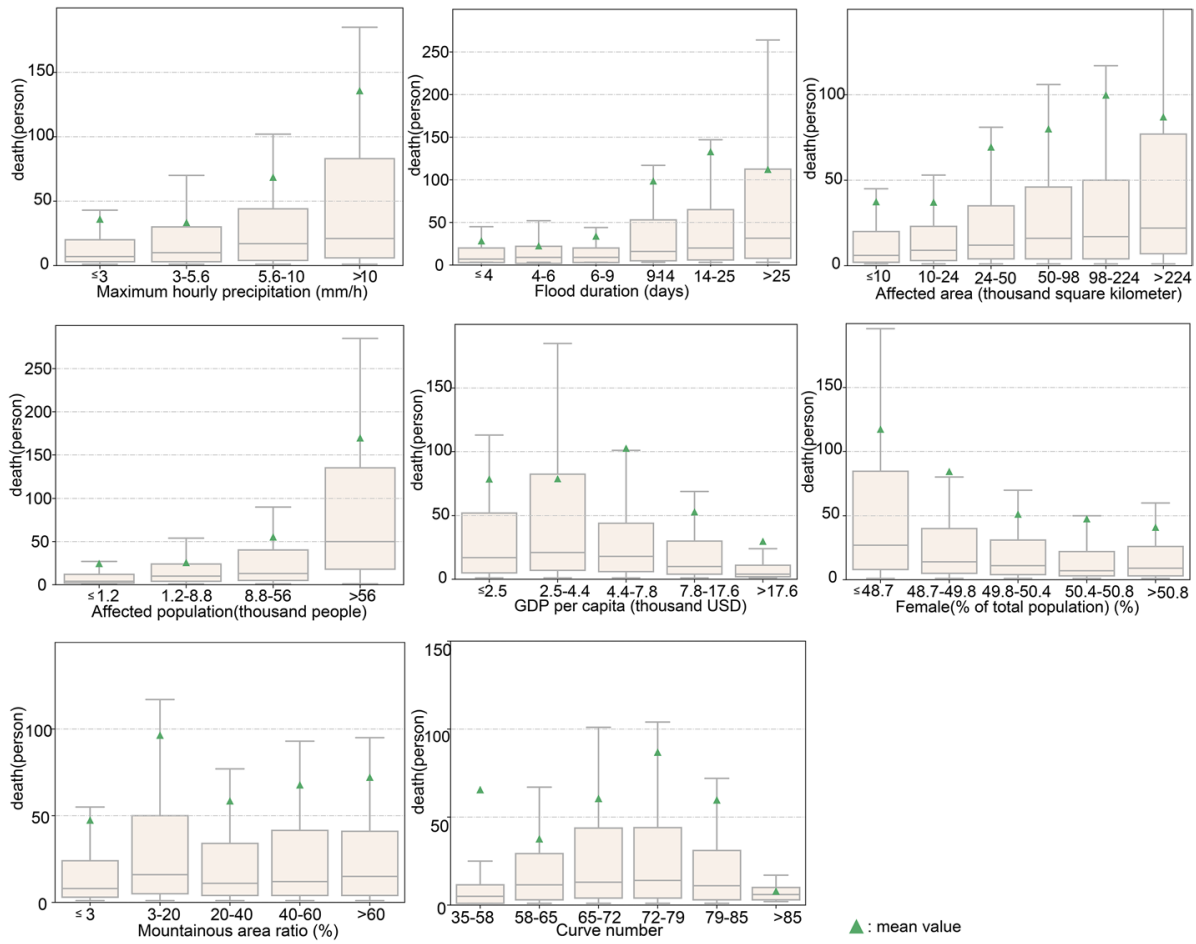

$\Delta$ : mean value

Fig. 6 Box plots of the mortality per flood event in subgroups of eight influencing factors 


\section{Discussion}

\subsection{Comparison of the contribution of influencing factors to the spatial pattern of flood-induced mortality}

Among all the influencing factors, the q value of the affected population was the largest, indicating affected population had the strongest impact on the spatial pattern of floodinduced mortality. Peduzzi et al. (2009) indicated that physical exposure (a function of flood frequency and population affected) is the major cause of flood-induced casualties. In this study, GDP per capita had the second largest influence on flood-induced mortality, which can be regarded as a measure of economic development and an indirect indicator of flood protection level or coping capacity (Dankers and Feyen 2009; Shi et al. 2016). When GDP per capita is below 4.4 thousand USD (constant 2011 international US dollar), deaths increased with increases in the economy, which may have been due to increased exposure as people move to wealthier coastal areas or floodplains. When the economy grows to a certain level, improvements in disaster prevention may help to reduce the death toll of floods with socioeconomic and technological developments (Hu et al. 2018). The flood-induced mortality was negatively associated with the percentage of females in total population, probably because women are usually more cautious during disasters and tend to escape them, while men are more likely to undertake outdoor activities and higher-risk jobs that could affect their ability to survive these events. Therefore, among the deaths caused by floods, the percentage of men was much higher than that of women, a result that was also found in some previous studies (Jonkman and Kelman 2005; Fitzgerald et al. 2010). The curve number reflects the underlying surface process of runoff generation and is a function of various factors, such as soil, land cover, and antecedent moisture conditions. A higher curve number value indicates a greater capacity to generate runoff (Zeng et al. 2017). Lastly, in general, higher values of maximum hourly precipitation and flood duration were associated with higher mortality.

This paper further compared the differences in the contributions of influencing factors for floods with different affected areas and for regions with mountainous area ratios, as shown in Fig. 7 and Fig. 8, respectively. In general, the contribution of each factor (except CN)

\begin{tabular}{|c|c|c|c|c|c|c|c|}
\hline & $\begin{array}{l}\text { Affected } \\
\text { population }\end{array}$ & GDPper & $\begin{array}{l}\text { Female (\%) } \\
\text { of total } \\
\text { population }\end{array}$ & $\begin{array}{l}\text { Flood } \\
\text { duration }\end{array}$ & $\begin{array}{l}\text { Curve } \\
\text { number }\end{array}$ & $\begin{array}{l}\text { Maximum } \\
\text { hourly } \\
\text { precipitation }\end{array}$ & $\begin{array}{l}\text { mountainous } \\
\text { area ratio }\end{array}$ \\
\hline Level I Flood & 11.0 & $10^{* *}$ & $3.2^{* *}$ & $2.8^{* *}$ & $2.9^{* *}$ & $2^{* *}$ & 1.3 \\
\hline Level II Flood & 2 & 12 & $4.5^{* *}$ & $7.2^{* *}$ & $5.1^{* *}$ & $4.3^{* *}$ & $2.3^{*}$ \\
\hline Level III Flood & $33.1^{* *}$ & $16.9^{*}$ & $14.7^{* *}$ & $10.8^{* *}$ & 1.9 & $4.8^{* *}$ & $9^{\text {** }}$ \\
\hline
\end{tabular}

Fig. 7 Contribution of influencing factors to the heterogeneity of flood-induced mortality for floods with different affected areas. **: Significant at the 5\% significance level, *: Significant at the $10 \%$ significance level 


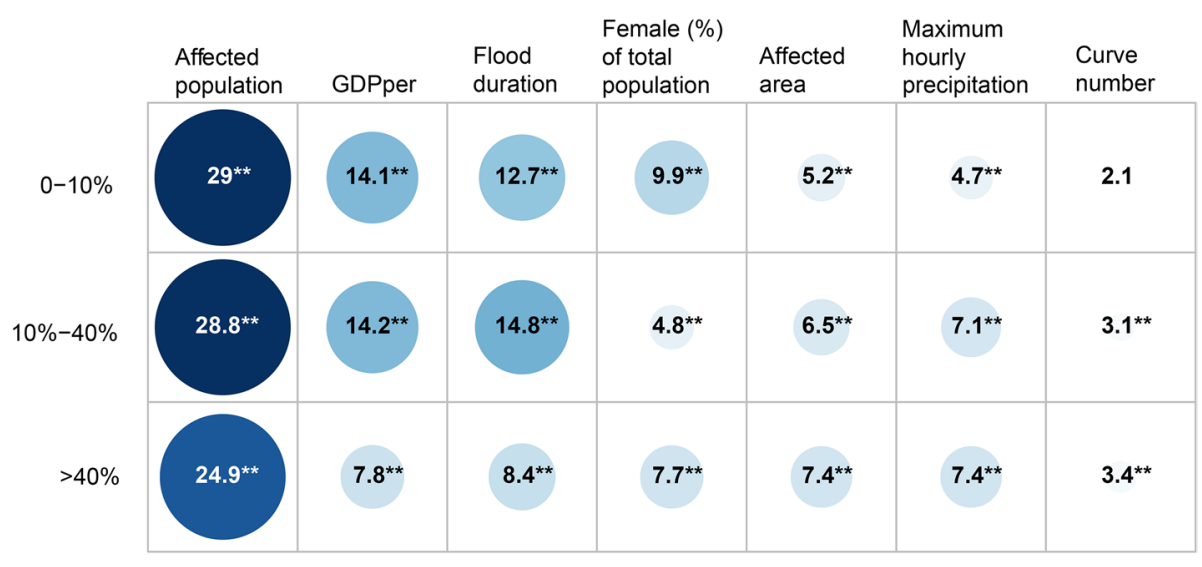

Fig. 8 Contribution of influencing factors to the heterogeneity of flood-induced mortality for flood-affected areas with different percentages of mountainous area. **: Significant at the $5 \%$ significance level

increased with the increase in flood-affected areas. This indicates that for floods with larger affected areas, the influence of most factors on flood-induced mortality is more significant.

For flood-affected areas with different mountainous area ratios, the impacts of affected population, GDP per capita and flood duration on flood-induced mortality were more significant in areas with lower mountainous area percentages $(\leq 40 \%)$ (Fig. 8$)$. There are generally more people and wealth in the middle-lower river plains than in upper mountainous areas, so different levels of human exposure and economic development would have a greater impact on flood-induced mortality in areas with fewer mountains. Floods in these areas are mainly fluvial floods that last for a long time. Long flood durations are often caused by persistent and recurrent rainfall, which could magnify the impact on humans (Najibi and Devineni 2018). Therefore, flood duration had a greater impact in areas with less mountains. Flash floods mainly occur in mountainous areas with rapid and intense processes; therefore, maximum hourly precipitation had a greater impact in areas with more mountainous areas (proportion over 40\%).

To further examine the impact of extreme rainfall on flood mortality in regions with different mountainous area ratios, we calculated the average deaths from flood events with different categories of mountainous area percentages and maximum hourly rainfall (Table 6). When the maximum hourly rainfall of the events was $0-10 \mathrm{~mm}$, the average flood-induced deaths were higher in regions with mountainous area ratios less than $10 \%$. The floods with maximum hourly rainfall less than $10 \mathrm{~mm} / \mathrm{h}$ were mainly fluvial floods, which generally last for a long time and occur in fluvial plains along rivers and estuarine deltas. These regions are usually densely populated, so the average mortality was higher. However, when the rainfall intensity exceeded $10 \mathrm{~mm} / \mathrm{h}$, the average mortality of each flood event was higher in regions that had more than $40 \%$ mountainous areas (Table 6). These mountainous areas are more prone to heavy rainfall related hazards such as flash floods and debris flows because

Table 6 Average flood-induced deaths at different categories of mountainous area ratio and maximum hourly rainfall

\begin{tabular}{llll}
\hline & $0-5 \mathrm{~mm} / \mathrm{h}$ & $5-10 \mathrm{~mm} / \mathrm{h}$ & $>10 \mathrm{~mm} / \mathrm{h}$ \\
\hline$\leq 10 \%$ & 203 & 418 & 60 \\
$10-40 \%$ & 63 & 74 & 135 \\
$>40 \%$ & 38 & 51 & 151 \\
\hline
\end{tabular}


of their topography and geological characteristics. In comparison to other catchment types, steeper catchments transport surface runoff more quickly (Tetzlaff et al. 2009; Chang et al. 2014); quicker transmission leads to more erosion of soil (Stein et al. 2021). In sloped areas, heavy rainfall increases positive pore pressure, which causes instability in the hillside and may result in landslides (Arango et al. 2020). When rainfall intensity reaches a certain threshold, the higher the proportion of mountainous areas is, the higher the probability for the occurrence of related hazards and the higher the average number of deaths. This also explains why extreme rainfall had higher contribution rate to the spatial pattern of flood mortality in areas with higher mountainous area percentages (Fig. 8). Therefore, more attention should be given to mountainous areas when there is heavy rainfall.

\subsection{Implications for flood management strategies}

Flood risk management at different scales depend on the natural environment and socioeconomic context, and multi-level decisions are needed according to the actual situation. Traditional flood prevention and control measures include the construction and maintenance of reservoirs, floodwalls and other engineering flood defences, also known as "hard flood protection strategies". In addition, "soft flood protection strategies" have received more and more attention, which include conducting spatial planning that takes into account flood risk, developing laws and regulations on risk management, and nature-based measures, such as returning farmland to forests and lakes, building wetland parks (Filatova 2014; Du et al. 2019, 2020; Qi et al. 2021). Regardless of the scale of flood disaster, it is necessary to adopt a integrated strategy of hard and soft measures, while risk management and adaptation strategies focus on different aspects for floods of different scales.

Large-scale floods mainly occur in large river basins, such as the Yangtze River Basin, Ganges River Basin and Mississippi River Basin, that usually cover different administrative regions. Flood risk management often involves interprovincial or interstate cooperation and should focus more on comprehensive coordination of upstream, middle and downstream areas. Flood protection cannot be limited to the segment of the river where the flood occurs since sometimes inappropriate measures upstream can endanger downstream regions. Therefore, for transprovincial flood management, it is more appropriate to establish institution of higher level and adopt a systematic approach for the whole basin, which highlights watershed management efforts, such as strengthening soil and water conservation in the upper reaches of rivers, dredging river channels, and replenishing and restoring flood storage and retention areas. Transnational flood risk management is more complex, and multinational cooperation is needed to coordinate the conflicts of interest between countries. For transnational rivers, it is a good choice to establish cooperation mechanisms within the basin, e.g. Mekong River Commission (MRC) and International Commission for the Protection of the Rhine (ICPR) (Becker et al. 2007). The cooperation mechanism enables the timely communication between different countries and institutions, and improves the efficiency and effectiveness of flood risk management.

Medium and relatively small floods are mainly located in coastal areas such as the Philippines, Malaysia, Vietnam, and the United Kingdom, and mountainous areas such as the Brahmaputra River Basin. Coastal floods are usually caused by two or more factors, including storm surges, waves, tides, precipitation, and high river discharges (Paprotny et al. 2020). Therefore, more consideration should be given to compound floods in coastal areas, and the monitoring of these compound factors should be strengthened in a broader scope of coastal management. In mountainous areas, extreme rainfall and curve number have a 
greater impact on flood-induced mortality (Fig. 8). Therefore, the ability for the monitoring, forecasting and early warning of heavy rainfall and related geological hazards should be improved. In addition, soil and water conservation in mountainous areas is also very important for flood risk reduction. In mountainous areas with frequent floods, it is necessary to carry out geological disaster investigations, communicate and share information on flood and geological disaster management modes.

\subsection{Outlook for future study}

The patterns of floods with different scales vary in different regions. This paper provides some information that can help governments and nongovernmental institutions develop macro-decisions related to flood risk management at different scales. However, this study also has some limitations. Firstly, the availability of long-term data and the precision of flood information will affect the results of the research. In future study, more datasets of historical flood events are still needed to be developed from more sources and with more dimensions of information on flood hazard and impacts. For example, it is necessary to identify inundation extent and water depth of each flood event based on remote sensing or hydrologic modelling, and to improve the quality on flood disaster loss through a combination with information from social media and other sources. More detailed information on flood events can help gain a deeper understanding of the formation of flood losses. In addition, the formation of disaster loss is rather complex, which is determined by the interaction between hazards, vulnerability and the environment. The quantification of more vulnerability factors and environmental factors (meteorological, hydrologic and geomorphic), as well as their interactions that affect flood disasters in different regions, needs to be studied more in the future.

\section{Conclusion}

Based on global flood events data from the DFO database for 1985-2019, this study analysed the distribution for the occurrence of floods with different flood-affected areas around the world, explored the driving factors behind the spatial differentiation in flood-induced mortality, and the following conclusions were reached:

The increase in global flood frequency has been mainly caused by the increase in the frequency of Level II and Level III floods, and the average affected area of individual flood event has been increasing yearly. At the global scale, the areas with high flood frequency were mainly distributed in the major basins and coastal areas of low latitudes in the Northern Hemisphere. Level I and Level II floods mainly occurred in coastal areas and Europe, and most Level III floods were distributed in the middle and lower reaches of major rivers. 
Among the three categories of floods, Level III floods in America and Africa caused the most cumulative deaths, and the frequency of Level III floods showed an increasing trend. Therefore, more attention should be given to Level III floods in these regions. Level II floods were responsible for the majority of deaths in Southeast Asia, while preventing casualties from Level I floods deserves more consideration in Japan, Indonesia and other island countries.

At a global scale, the top three factors that contribute the most to the spatial heterogeneity of flood-induced mortality were the affected population, GDP per capita and flood duration. When the mountainous area ratio in flood-affected area was greater than $20 \%$, a higher proportion of mountains was associated with more flood-induced mortality.

Among the three categories of floods, the proportion of mountainous areas within the flood-affected area for Level III floods contributed the most to the spatial heterogeneity of flood-induced mortality. As the proportion of mountainous areas increased, the impacts of affected population and per capita GDP decreased, while the impacts of extreme rainfall and curve number gradually increased. Therefore, in flat areas with low mountainous area percentage, more attention should be given to increasing the level of flood protection and reducing social vulnerability to reduce flood risk. In addition, topographic factors magnified flood-induced mortality during flood events with heavy rainfall. In mountainous areas, we should pay attention to soil and water conservation, develop more effective instruments for the monitoring, forecasting and early warning on flash floods and secondary geological hazards.

\section{Appendix}

\section{Uncertainties and reliability of the global flood database}

The global flood event database from the DFO used in the study was derived from news and government reports and remote sensing, which may contribute to uncertainties in its coverage and loss estimates. This scenario is acceptable given the scope of global analysis.

Najibi and Devineni (2018) compared the frequency of floods in the DFO database with that in EM-DAT. The flood frequency in EM-DAT has a similar trend to that of the DFO database with a significant correlation coefficient of 0.636. Moreover, the DFO database contains more flood events. One reason for the higher number of flood events in the DFO database may be the difference in criteria between the two databases; another reason is that the DFO database has more sources, such as satellite observations. For example, the DFO collects information flood events in areas where there is no reporting facility using MODIS (Moderate-Resolution Imaging Spectroradiometer) sensors. The quality and quantity of news reporting data often vary with the level of development and technology of different countries. In comparison with the runoff data from the Global Runoff Data Centre 
Table 7 Distribution of the deviation in flood-induced mortality between the DFO database and HANZE

\begin{tabular}{ll}
\hline Deviation in flood-induced mortality & $\begin{array}{l}\text { Cumulative percent- } \\
\text { age of frequency } \\
(\%)\end{array}$ \\
\hline 0 & 50.2 \\
1 & 62.3 \\
$1<\leq 5$ & 84.8 \\
$5<\leq 10$ & 94.8 \\
$>10$ & 100 \\
\hline
\end{tabular}

Statistics of the top 30 countries with the highest flood frequencies, flood-induced mortality, and affected populations

(GRDC), flood events in the DFO database matched the runoff process for approximately $80 \%$ of the stations in the middle latitudes and subtropics, demonstrating that the flood start-end dates recorded in the DFO database are reliable (Najibi and Devineni 2018).

We also conducted an evaluation of the flood-induced mortality recorded in the DFO database through a comparison with the European historical flood database HANZE (1870-2016). The HANZE data are derived from a total of 307 sources, including national and international databases, such as EM-DAT, European Environment Agency, and Munich Re, and scientific papers and books (Paprotny et al. 2018b). The events in the two databases were first matched according to their start-end dates and location. If the flood events in two databases occurred in the same time period and the extent of the flood events in the DFO database covered the administrative region mentioned in HANZE, then the two databases were considered to match each other. Since the events in HANZE are based on countries and the area affected by a flood event recorded in the DFO database may include the territory of multiple countries, one flood event in the DFO database may correspond to several events in HANZE. There were 321 flood events in the DFO database from the 25 European countries from 1985 to 2016, of which 236 events were recorded in the HANZE database. The deviation in flood-induced mortality for the 236 flood events from these two databases was then calculated, and the cumulative frequency distribution was analysed (as shown in Table 7, see in Appendix). Approximately 50\% of the matched events had no deviation in flood-induced mortality, $85 \%$ had a deviation of no more than 5 deaths, and $95 \%$ of the events had a deviation of no more than 10 deaths. This result indicates that the flood-induced mortality information in the DFO database is relatively reliable at the regional scale and can be used for global analysis (Tables 8, 9, 10). 


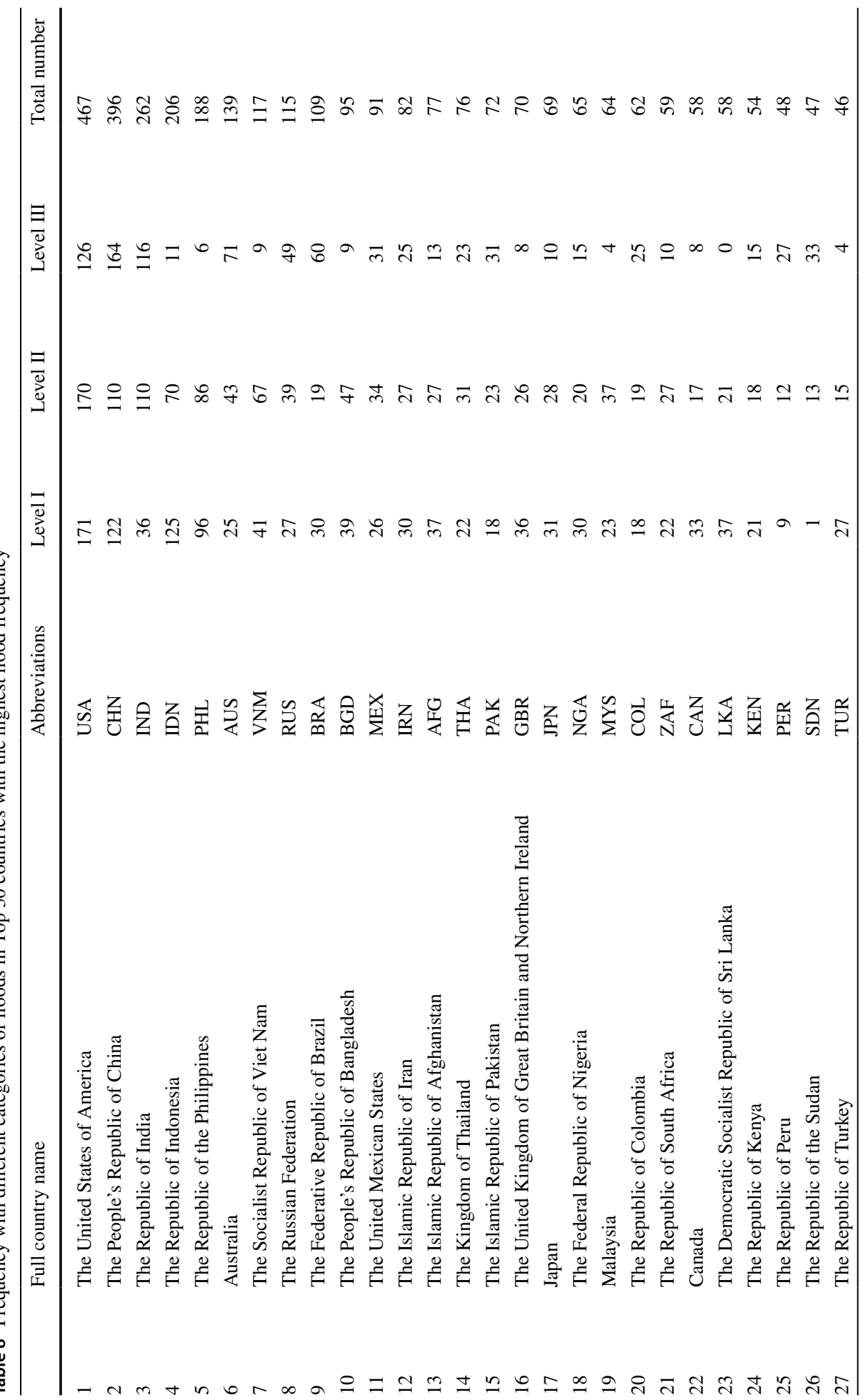




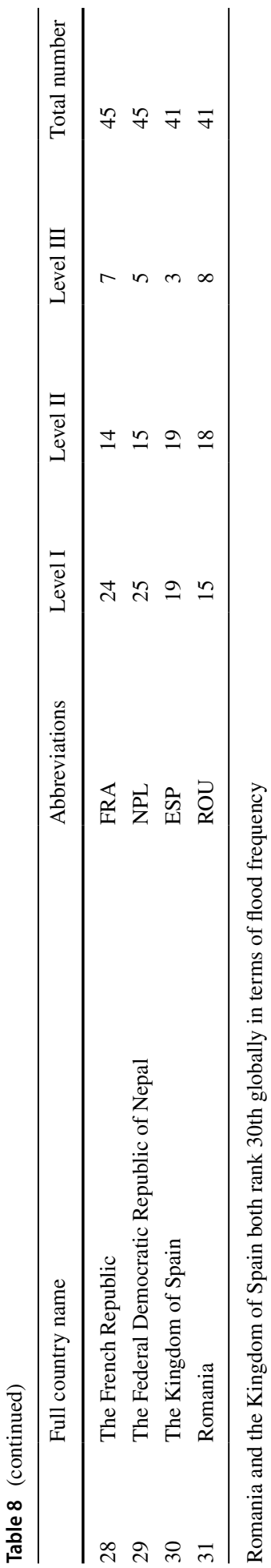


Table 9 Mortality with different categories of floods in Top 30 countries with the highest flood mortality. Unit: Person

\begin{tabular}{|c|c|c|c|c|c|c|}
\hline & Full country name & Abbreviations & Level I & Level II & Level III & Total number \\
\hline 1 & The Kingdom of Thailand & THA & 506 & 162,471 & 917 & 163,894 \\
\hline 2 & The People's Republic of Bangladesh & BGD & 1846 & 143,256 & 5769 & 150,871 \\
\hline 3 & The Republic of the Union of Myanmar & MMR & 5 & 100,210 & 166 & 100,381 \\
\hline 4 & The Republic of India & IND & 1800 & 9819 & 42,015 & 53,634 \\
\hline 5 & The People's Republic of China & $\mathrm{CHN}$ & 4592 & 7952 & 22,190 & 34,734 \\
\hline 6 & The Bolivarian Republic of Venezuela & VEN & 180 & 105 & 20,051 & 20,336 \\
\hline 7 & The Republic of the Philippines & PHL & 2368 & 14,522 & 1974 & 18,864 \\
\hline 8 & The Republic of Honduras & HND & 267 & 119 & 11,011 & 11,397 \\
\hline 9 & Japan & JPN & 10,284 & 516 & 265 & 11,065 \\
\hline 10 & The Islamic Republic of Pakistan & PAK & 590 & 1515 & 8685 & 10,790 \\
\hline 11 & The Socialist Republic of Viet Nam & VNM & 946 & 3832 & 1087 & 5865 \\
\hline 12 & The Republic of Indonesia & IDN & 3182 & 1642 & 336 & 5160 \\
\hline 13 & The Islamic Republic of Afghanistan & AFG & 397 & 3628 & 961 & 4986 \\
\hline 14 & The United States of America & USA & 794 & 1689 & 2375 & 4858 \\
\hline 15 & The Federal Republic of Somalia & SOM & 67 & 137 & 4448 & 4652 \\
\hline 16 & The Republic of Costa Rica & CRI & 67 & 4041 & 0 & 4108 \\
\hline 17 & The United Republic of Tanzania & TZA & 3689 & 143 & 275 & 4107 \\
\hline 18 & The Dominican Republic & DOM & 3384 & 549 & 0 & 3933 \\
\hline 19 & The Federative Republic of Brazil & BRA & 1267 & 353 & 2176 & 3796 \\
\hline 20 & The Republic of Haiti & HTI & 220 & 566 & 3006 & 3792 \\
\hline 21 & The Republic of Colombia & $\mathrm{COL}$ & 309 & 1229 & 1277 & 2815 \\
\hline 22 & $\begin{array}{l}\text { The Federal Democratic Republic of } \\
\text { Nepal }\end{array}$ & NPL & 981 & 1048 & 723 & 2752 \\
\hline 23 & The United Mexican States & MEX & 277 & 1054 & 1310 & 2641 \\
\hline 24 & The Islamic Republic of Iran & IRN & 286 & 958 & 1323 & 2567 \\
\hline 25 & The Republic of Nicaragua & NIC & 153 & 2136 & 158 & 2447 \\
\hline 26 & The Republic of El Salvador & SLV & 266 & 48 & 2000 & 2314 \\
\hline 27 & The Kingdom of Cambodia & KHM & 267 & 655 & 1260 & 2182 \\
\hline 28 & The Republic of Malawi & MWI & 527 & 932 & 402 & 1861 \\
\hline 29 & The Republic of Korea & KOR & 912 & 905 & 34 & 1851 \\
\hline 30 & $\begin{array}{l}\text { The Democratic People's Republic of } \\
\text { Korea }\end{array}$ & PRK & 211 & 1318 & 273 & 1802 \\
\hline
\end{tabular}


Table 10 Population affected by floods with different categories in Top 30 countries with the highest affected population. Unit: Million person

\begin{tabular}{|c|c|c|c|c|c|c|}
\hline & Full country name & Abbreviations & Level I & Level II & Level III & Total number \\
\hline 1 & The Republic of India & IND & 1.62 & 18.40 & 164.97 & 184.99 \\
\hline 2 & The People's Republic of Bangladesh & BGD & 17.98 & 37.79 & 76.15 & 131.92 \\
\hline 3 & The People's Republic of China & $\mathrm{CHN}$ & 3.54 & 17.39 & 99.24 & 120.16 \\
\hline 4 & The Republic of Nicaragua & NIC & 0.08 & 27.61 & 0.14 & 27.83 \\
\hline 5 & The Islamic Republic of Pakistan & PAK & 0.01 & 2.07 & 19.16 & 21.24 \\
\hline 6 & The Republic of the Philippines & PHL & 6.78 & 12.27 & 2.04 & 21.09 \\
\hline 7 & The Kingdom of Thailand & THA & 0.16 & 10.18 & 8.27 & 18.60 \\
\hline 8 & The Socialist Republic of Viet Nam & VNM & 3.01 & 7.07 & 2.53 & 12.62 \\
\hline 9 & $\begin{array}{l}\text { THE Federal Democratic Republic of } \\
\text { Nepal }\end{array}$ & NPL & 0.35 & 0.22 & 10.02 & 10.59 \\
\hline 10 & The United States of America & USA & 1.00 & 5.49 & 2.54 & 9.02 \\
\hline 11 & The Kingdom of Cambodia & KHM & 0.29 & 1.88 & 6.66 & 8.82 \\
\hline 12 & $\begin{array}{l}\text { The Democratic Socialist Republic of } \\
\text { Sri Lanka }\end{array}$ & LKA & 4.36 & 3.26 & 0.00 & 7.62 \\
\hline 13 & Japan & JPN & 1.15 & 1.76 & 2.40 & 5.32 \\
\hline 14 & The Republic of Colombia & $\mathrm{COL}$ & 0.11 & 2.55 & 2.64 & 5.30 \\
\hline 15 & The Republic of the Sudan & SDN & 0.00 & 0.49 & 3.99 & 4.48 \\
\hline 16 & The Republic of Indonesia & IDN & 2.46 & 1.75 & 0.19 & 4.40 \\
\hline 17 & The United Republic of Tanzania & TZA & 0.04 & 0.05 & 4.23 & 4.32 \\
\hline 18 & The United Mexican States & MEX & 0.36 & 1.49 & 2.25 & 4.10 \\
\hline 19 & The Federative Republic of Brazil & BRA & 0.20 & 0.71 & 2.60 & 3.50 \\
\hline 20 & The Republic of Kenya & KEN & 0.15 & 0.15 & 2.55 & 2.85 \\
\hline 21 & The Republic of Mozambique & $\mathrm{MOZ}$ & 0.02 & 0.71 & 1.97 & 2.70 \\
\hline 22 & The Republic of Honduras & HND & 0.05 & 0.34 & 2.01 & 2.40 \\
\hline 23 & The Republic of the Union of Myanmar & MMR & 0.02 & 1.89 & 0.31 & 2.22 \\
\hline 24 & The Federal Republic of Nigeria & NGA & 0.30 & 0.67 & 1.19 & 2.15 \\
\hline 25 & $\begin{array}{l}\text { The Democratic People's Republic of } \\
\text { Korea }\end{array}$ & PRK & 0.12 & 0.79 & 1.04 & 1.95 \\
\hline 26 & The Republic of Korea & KOR & 1.56 & 0.13 & 0.16 & 1.85 \\
\hline 27 & The Russian Federation & RUS & 0.10 & 0.17 & 1.41 & 1.67 \\
\hline 28 & The Republic of Madagascar & MDG & 0.07 & 0.28 & 1.25 & 1.60 \\
\hline 29 & The Republic of Peru & PER & 0.01 & 0.52 & 1.02 & 1.55 \\
\hline 30 & The Republic of Azerbaijan & AZE & 0.01 & 1.50 & 0.00 & 1.51 \\
\hline
\end{tabular}

Acknowledgements This work has been supported by the National Key Research \& Development programme of China (Grant numbers: 2016YFA0602404), China Scholarship Council, and Expertise-Introduction Project for Disciplinary Innovation of Universities (111 Project)- Hazard and Risk Science Base at Beijing Normal University 2.0 (Grant numbers: BP0820003) and National Natural Science Foundation of China (Grant numbers: 42077441).

Author contribution PS and TL designed the research. JF and TL collected data. TL conducted analysis and drafted the manuscript, PS and JF commented on previous versions of the manuscript. All authors read and approved the final manuscript.

Data availability The links to download all the data are in Table 1. 


\section{Declarations}

Conflict of interest The authors declare that they have no conflict of interest.

Open Access This article is licensed under a Creative Commons Attribution 4.0 International License, which permits use, sharing, adaptation, distribution and reproduction in any medium or format, as long as you give appropriate credit to the original author(s) and the source, provide a link to the Creative Commons licence, and indicate if changes were made. The images or other third party material in this article are included in the article's Creative Commons licence, unless indicated otherwise in a credit line to the material. If material is not included in the article's Creative Commons licence and your intended use is not permitted by statutory regulation or exceeds the permitted use, you will need to obtain permission directly from the copyright holder. To view a copy of this licence, visit http://creativecommons.org/licenses/by/4.0/.

\section{References}

Global Modeling and Assimilation Office (GMAO) (2015) MERRA-2 tavg1_2d_lnd_Nx: 2d,1-Hourly, Time-Averaged, Single-Level, Assimilation, Land Surface Diagnostics V5.12.4, Goddard Earth Sciences Data and Information Services Center (GES DISC), https://doi.org/10.5067/RKPHT8KC1Y1T

Ali R, Kuriqi A, Abubaker S, Kisi O (2019) Long-term trends and seasonality detection of the observed flow in Yangtze River using Mann-Kendall and Sen's innovative trend method. Water (switzerland). https://doi.org/10.3390/w11091855

Arango MI, Aristizábal E, Gómez F (2020) Morphometrical analysis of torrential flows-prone catchments in tropical and mountainous terrain of the Colombian Andes by machine learning techniques. Nat Hazards. https://doi.org/10.1007/s11069-020-04346-5

Becker G, Aerts JCJ, Huitema D (2007) Transboundary flood management in the Rhine basin: challenges for improved cooperation. Water Sci Technol 56:125-135. https://doi.org/10.2166/wst.2007.544

Berghuijs WR, Allen ST, Harrigan S, Kirchner JW (2019) Growing spatial scales of synchronous river flooding in Europe. Geophys Res Lett 46:1423-1428. https://doi.org/10.1029/2018GL081883

Brakenridge GR (2020) Global active archive of large flood events. Dartmouth Flood Observatory, University of Colorado, USA. http://floodobservatory.colorado.edu/Archives/index.html. Accessed 25 Feb 2020

Cao F, Ge Y, Wang JF (2013) Optimal discretization for geographical detectors-based risk assessment. Giscience Remote Sens 50:78-92. https://doi.org/10.1080/15481603.2013.778562

Chang H, Johnson G, Hinkley T, Jung IW (2014) Spatial analysis of annual runoff ratios and their variability across the contiguous U.S. J Hydrol 511:387-402. https://doi.org/10.1016/j.jhydrol.2014.01. 066

Chen B, Shi F, Lin T et al (2020a) Intensive versus extensive events? insights from cumulative floodinduced mortality over the Globe, 1976-2016. Int J Disaster Risk Sci 11:441-451. https://doi.org/10. $1007 / \mathrm{s} 13753-020-00288-5$

Chen A, Giese M, Chen D (2020b) Flood impact on Mainland Southeast Asia between 1985 and 2018-The role of tropical cyclones. J Flood Risk Manag 13:1-13. https://doi.org/10.1111/jfr3.12598

Dankers R, Feyen L (2009) Flood hazard in Europe in an ensemble of regional climate scenarios. J Geophys Res Atmos. https://doi.org/10.1029/2008JD011523

Delgado JM, Apel H, Merz B (2010) Flood trends and variability in the Mekong river

Di Mauro M, De Bruijn KM, Meloni M (2012) Quantitative methods for estimating flood fatalities: towards the introduction of loss-of-life estimation in the assessment of flood risk. Nat Hazards 63:1083-1113. https://doi.org/10.1007/s11069-012-0207-4

Du S, Cheng X, Huang Q et al (2019) Brief communication: rethinking the 1998 China floods to prepare for a nonstationary future. Nat Hazards Earth Syst Sci 19:715-719. https://doi.org/10.5194/ nhess-19-715-2019

Du S, Scussolini P, Ward PJ et al (2020) Hard or soft flood adaptation? advantages of a hybrid strategy for Shanghai. Glob Environ Chang 61:102037. https://doi.org/10.1016/j.gloenvcha.2020.102037

Filatova T (2014) Market-based instruments for flood risk management: a review of theory, practice and perspectives for climate adaptation policy. Environ Sci Policy 37:227-242. https://doi.org/10.1016/j. envsci.2013.09.005 
Fitzgerald G, Du W, Jamal A et al (2010) Flood fatalities in contemporary Australia (1997-2008): disaster medicine. EMA Emerg Med Australas 22:180-186. https://doi.org/10.1111/j.1742-6723.2010.01284.X

Halgamuge MN, Nirmalathas A (2017) Analysis of large flood events: based on flood data during 19852016 in Australia and India. Int J Disaster Risk Reduct 24:1-11. https://doi.org/10.1016/j.ijdrr.2017. 05.011

Hallegatte S, Green C, Nicholls RJ, Corfee-Morlot J (2013) Future flood losses in major coastal cities. Nat Clim Chang 3:802-806. https://doi.org/10.1038/nclimate1979

Hanson S, Nicholls R, Ranger N et al (2011) A global ranking of port cities with high exposure to climate extremes. Clim Change 104:89-111. https://doi.org/10.1007/s10584-010-9977-4

Hirabayashi Y, Mahendran R, Koirala S et al (2013) Global flood risk under climate change. Nat Clim Chang 3:816-821. https://doi.org/10.1038/nclimate1911

Hu P, Zhang Q, Shi P et al (2018) Flood-induced mortality across the globe: spatiotemporal pattern and influencing factors. Sci Total Environ 643:171-182. https://doi.org/10.1016/j.scitotenv.2018.06.197

$\mathrm{Hu}$ Y, Wang J, Li X et al (2011) Geographical detector-based risk assessment of the under-five mortality in the 2008 Wenchuan earthquake. China Plos One. https://doi.org/10.1371/journal.pone.0021427

Jongman B, Hochrainer-Stigler S, Feyen L et al (2014) Increasing stress on disaster-risk finance due to large floods. Nat Clim Chang 4:264-268. https://doi.org/10.1038/nclimate2124

Jongman B, Ward PJ, Aerts JCJH (2012) Global exposure to river and coastal flooding: long term trends and changes. Glob Environ Chang 22:823-835. https://doi.org/10.1016/j.gloenvcha.2012.07.004

Jonkman SN (2005) Global perspectives on loss of human life caused by floods. Nat Hazards 34:151-175. https://doi.org/10.1007/s11069-004-8891-3

Jonkman SN, Kelman I (2005) An analysis of the causes and circumstances of flood disaster deaths. Disasters 29:75-97. https://doi.org/10.1111/j.0361-3666.2005.00275.x

Jonkman SN, Maaskant B, Boyd E, Levitan ML (2009) Loss of life caused by the flooding of New Orleans after hurricane Katrina: analysis of the relationship between flood characteristics and mortality. Risk Anal 29:676-698. https://doi.org/10.1111/j.1539-6924.2008.01190.x

Kellenberg DK, Mobarak AM (2008) Does rising income increase or decrease damage risk from natural disasters? J Urban Econ 63:788-802. https://doi.org/10.1016/j.jue.2007.05.003

Kemter M, Merz B, Marwan N et al (2020) Joint trends in flood magnitudes and spatial extents across Europe. Geophys Res Lett. https://doi.org/10.1029/2020GL087464

Kendall MG (1975) Rank correlation methods, 4th edn. Charles Griffin and Co., Ltd., London

Koç G, Thieken AH (2018) The relevance of flood hazards and impacts in Turkey: What can be learned from different disaster loss databases?

Kummu M, Taka M, Guillaume JHA (2018) Gridded global datasets for Gross Domestic Product and Human Development Index over 1990-2015. Sci Data 5:1-15. https://doi.org/10.1038/sdata.2018.4

Luo L, Mei K, Qu L et al (2019) Assessment of the Geographical Detector Method for investigating heavy metal source apportionment in an urban watershed of Eastern China. Sci Total Environ 653:714-722. https://doi.org/10.1016/j.scitotenv.2018.10.424

Mann HB (1945) Nonparametric tests against trend. Econometrica 13:245-259

Najibi N, Devineni N (2018) Recent trends in the frequency and duration of global floods. Earth Syst Dyn 9:757-783. https://doi.org/10.5194/esd-9-757-2018

Naz F, Saqib SE (2021) Gender-based differences in flood vulnerability among men and women in the char farming households of Bangladesh. Nat Hazards 106:655-677. https://doi.org/10.1007/ s11069-020-04482-y

Neumann B, Vafeidis AT, Zimmermann J, Nicholls RJ (2015) Future coastal population growth and exposure to sea-level rise and coastal flooding-a global assessment. PLoS ONE 10:103. https://doi.org/10. 1371/journal.pone.0118571

Paprotny D, Morales-nápoles O, Jonkman SN (2018b) HANZE : a pan-European database of exposure to natural hazards and damaging historical floods since 1870. Earth Syst Sci Data 2:565-581

Paprotny D, Sebastian A, Morales-Nápoles O, Jonkman SN (2018a) Trends in flood losses in Europe over the past 150 years. Nat Commun. https://doi.org/10.1038/s41467-018-04253-1

Paprotny D, Vousdoukas MI, Morales-Nápoles O et al (2020) Pan-European hydrodynamic models and their ability to identify compound floods. Nat Hazards 101:933-957. https://doi.org/10.1007/ s11069-020-03902-3

Peduzzi P, Dao H, Herold C, Mouton F (2009) Assessing global exposure and vulnerability towards natural hazards: the Disaster Risk Index. Nat Hazards Earth Syst Sci 9:1149-1159. https://doi.org/10.5194/ nhess-9-1149-2009

Qi W, Ma C, Xu H et al (2021) A review on applications of urban flood models in flood mitigation strategies. Springer, Netherlands 
Sen PK (1968) Estimates of the regression coefficient based on Kendall's tau. J Am Stat Assoc 63:1379-1389

Shen G, Hwang SN (2019) Spatial-Temporal snapshots of global natural disaster impacts Revealed from EM-DAT for 1900-2015. Geomatics, Nat Hazards Risk 10:912-934. https://doi.org/10.1080/19475 705.2018.1552630

Shi P (2019) Disaster Risk Science, second. Springer, Singapore

Shi P (1996) Theory and practice of disaster study. J Nat Disaster 5:6-17. https://doi.org/10.13577/j.jnd. 1996.0402

Shi P, Yang X, Fang J et al (2016) Mapping and ranking global mortality, affected population and GDP loss risks for multiple climatic hazards. J Geogr Sci 26:878-888. https://doi.org/10.1007/ s11442-016-1304-1

Song Y, Wang J, Ge Y, Xu C (2020) An optimal parameters-based geographical detector model enhances geographic characteristics of explanatory variables for spatial heterogeneity analysis: cases with different types of spatial data. Gisci Remote Sens 57:593-610. https://doi.org/10.1080/15481603.2020. 1760434

Stein L, Clark MP, Knoben WJM et al (2021) How do climate and catchment attributes influence flood generating processes? A large-sample study for 671 catchments across the contiguous USA. Water Resour Res. https://doi.org/10.1029/2020wr028300

Stevens AJ, Clarke D, Nicholls RJ (2016) Trends in reported flooding in the UK: 1884-2013. Hydrol Sci J 61:50-63. https://doi.org/10.1080/02626667.2014.950581

Tanoue M, Hirabayashi Y, Ikeuchi H (2016) Global-scale river flood vulnerability in the last 50 years. Sci Rep 6:1-9. https://doi.org/10.1038/srep36021

Tetzlaff D, Seibert J, McGuire KJ et al (2009) How does landscape structure influence catchment transit time across different geomorphic provinces? Hydrol Process 23:945-953. https://doi.org/10.1002/hyp. 7240

UNEP/WCMC (2020) Mountain and Mountain Forest. https://www.unep-wcmc.org/. Accessed 23 July 2020

Villarini G, Smith JA, Baeck ML et al (2011) Characterization of rainfall distribution and flooding associated with U.S. landfalling tropical cyclones: analyses of Hurricanes Frances, Ivan, and Jeanne. J Geophys Res Atmos. https://doi.org/10.1029/2011JD016175

Wang J, Xu C (2017) Geodetector: principle and prospective. Acta Geogr Sin 72:116-134. https://doi.org/ $10.11821 / \mathrm{dl} x \mathrm{xb} 201701010$

Wang JF, Hu Y (2012) Environmental health risk detection with GeogDetector. Environ Model Softw 33:114-115. https://doi.org/10.1016/j.envsoft.2012.01.015

Wang JF, Li XH, Christakos G et al (2010) Geographical detectors-based health risk assessment and its application in the neural tube defects study of the Heshun Region, China. Int J Geogr Inf Sci 24:107127. https://doi.org/10.1080/13658810802443457

World Bank (2020) World Bank Open Data. https://data.worldbank.org/. Accessed 20 Feb 2020

Zeng Z, Tang G, Hong Y et al (2017) Development of an NRCS curve number global dataset using the latest geospatial remote sensing data for worldwide hydrologic applications. Remote Sens Lett 8:528-536. https://doi.org/10.1080/2150704X.2017.1297544

Zhao G, Pang B, Xu Z et al (2018) Mapping flood susceptibility in mountainous areas on a national scale in China. Sci Total Environ 615:1133-1142. https://doi.org/10.1016/j.scitotenv.2017.10.037

Publisher's Note Springer Nature remains neutral with regard to jurisdictional claims in published maps and institutional affiliations. 